V.Vengatachalapathy, Dr.R.Ilangovan / IOSR Journal of Engineering (IOSRJEN)

www.iosrjen.org

ISSN : 2250-3021

Vol. 2 Issue 2, Feb.2012, pp.348-355

\title{
EXPERIMENTAL EVALUATION FOR STRENGTH OF STEEL FIBER REINFORCED CONCRETE DEEP BEAMS
}

\author{
V.Vengatachalapathy ${ }^{1}$, Dr.R.Ilangovan ${ }^{2}$ \\ ${ }^{1}$, Research scholar Anna University of Technology - Tiruchirapalli \\ 2, Assistant Professor, Civil Dept, Anna University of Technology - Tiruchirapalli
}

\begin{abstract}
This experimental study deals with the ultimate strength of reinforced concrete deep beams with and without openings in web subjected to two- point loading, seven concrete deep beams of dimensions $750 \mathrm{~mm} \times 350 \mathrm{~mm} \times 75 \mathrm{~mm}$ thickness were tested to destruction by applying gradually increased load. Simply supported conditions were maintained for all the concrete deep beams. The influence of fiber content in the concrete deep beams shear behavior has been studied by measuring the deflection of the deep beams and by observing the crack patterns.
\end{abstract}

Keywords: Deep beams; Beam -Web openings, Shear behavior, Steel fiber

\section{INTRODUCTION}

Concrete structural members having depth comparable to span are generally termed as deep beams. Deep beams are frequently used as structural members in construction works. In special cases, web openings are required to provide for services or for access. Because of the geometric proportions of deep beams, their strength is usually controlled by shear rather than flexure, if normal amounts of reinforcements are provided. A proliferation of new developments in steel fiber reinforced concrete technology has greatly extended the range of applications. The application currently depends on the ingenuity of the designer and builder taking advantage of the improved static and dynamic tensile strength, ductility, energy - absorbing characteristics, abrasion resistance, and fatigue strength of this new material of construction. The uniform dispersion of steel fiber throughout the concrete provided isotropic strength properties which are not exhibited by conventionally reinforced concrete. Previous studies have shown that a significant increase in the shear strength of deep beams with or without openings can be achieved by providing either conventional web reinforcement or steel fibers in the concrete matrix. The inclusion of fibers in a concrete matrix has been found to increase the shear strength, increase the first crack load, arrest the crack propagation, and enhance the fracture toughness, post-cracking ductility.

For the last two decades, a number of investigations are being carried out on the behavior of fiber reinforced composites. Since 1972, a number of experimental and analytical investigations have been carried out to study the behavior and collapse loads of deep beams with and without web opening. The openings are usually provided in such beams to have an access for utility ducts without further increases in ceiling head room. As the usage of those beams with or without openings increases, it becomes imperative that the design criteria of such beams is widely tested and established.

In the present examination, flat steel fibers were used. This investigation is a bid to study the shear behavior of deep beams reinforced with flat steel fibers instead of dramix fibers.

\section{Materials and Mix used}

Ordinary Portland cement of 53 grade with a specific gravity of 3.15 was used for all the specimens cast. The Fine Aggregate used for casting was clean river sand. The specific gravity of fine aggregate was 2.71 . The fineness modulus of the fine aggregate was 2.4. The coarse aggregate used was broken granite stone of size $10 \mathrm{~mm}$. The specific gravity of coarse aggregate was 2.84 . The bulk density of coarse aggregate was found to be $1640 \mathrm{~kg} / \mathrm{m}^{3}$. Bore well water available in the Structural Engineering laboratory was used for casting all specimens of this investigation. The quality of water was found to satisfy the requirements of IS $456-2000$.

Two steel rods of $16 \mathrm{~mm}$ diameter of $415 \mathrm{~N} / \mathrm{mm}^{2}$ yield strength were used as the main tension reinforcement. The bars were anchored by welding to $6 \mathrm{~mm}$ thick steel plates at both ends. Each beam contained web reinforcement consisting of two layers of welded wire fabric of $3.3 \mathrm{~mm}$ diameter and $50 \mathrm{~mm}$ on centers having yield strength of 300 $\mathrm{N} / \mathrm{mm}^{2}$. 


\section{V.Vengatachalapathy, Dr.R.Ilangovan / IOSR Journal of Engineering (IOSRJEN) www.iosrjen.org \\ ISSN : 2250-3021}

Vol. 2 Issue 2, Feb.2012, pp.348-355

Bearing plates and reinforcement cages were provided at supports and loading points to disperse the concentrated forces, thereby avoiding localized distress of concrete.

\section{Casting of Deep beams and its Companions}

M20 concrete mix of 1 (cement) : 1.5(F.A) : 3 ( C.A.) with water cement ratio by weight of 0.50 was used for making the standard concrete specimens and for deep beams. Cement and sand were first mixed then coarse aggregate was added and the materials were mixed thoroughly until uniformity was achieved. To this concrete mixture, the fiber of predetermined quantity were added and mixed, taking care to avoid bundling or balling. Then the required quantity of water was added slowly and wet mixing was done. At all stages, hand mixing was adapted and care was taken to ensure random distribution of fibers in the composites. A controlled internal vibration was used for the compaction of the cylinders and prismatic specimens. seven deep beams of size $750 \mathrm{~mm}$ x $325 \mathrm{~mm} \mathrm{x}$ $75 \mathrm{~mm}$ specimens with and without holes as shown in fig(1) were cast flat-wise and compacted on a vibration table in three layers. The specimens were kept under room temperature of 24 hours before demoulding. All the specimens were curried under wet gunny bags.

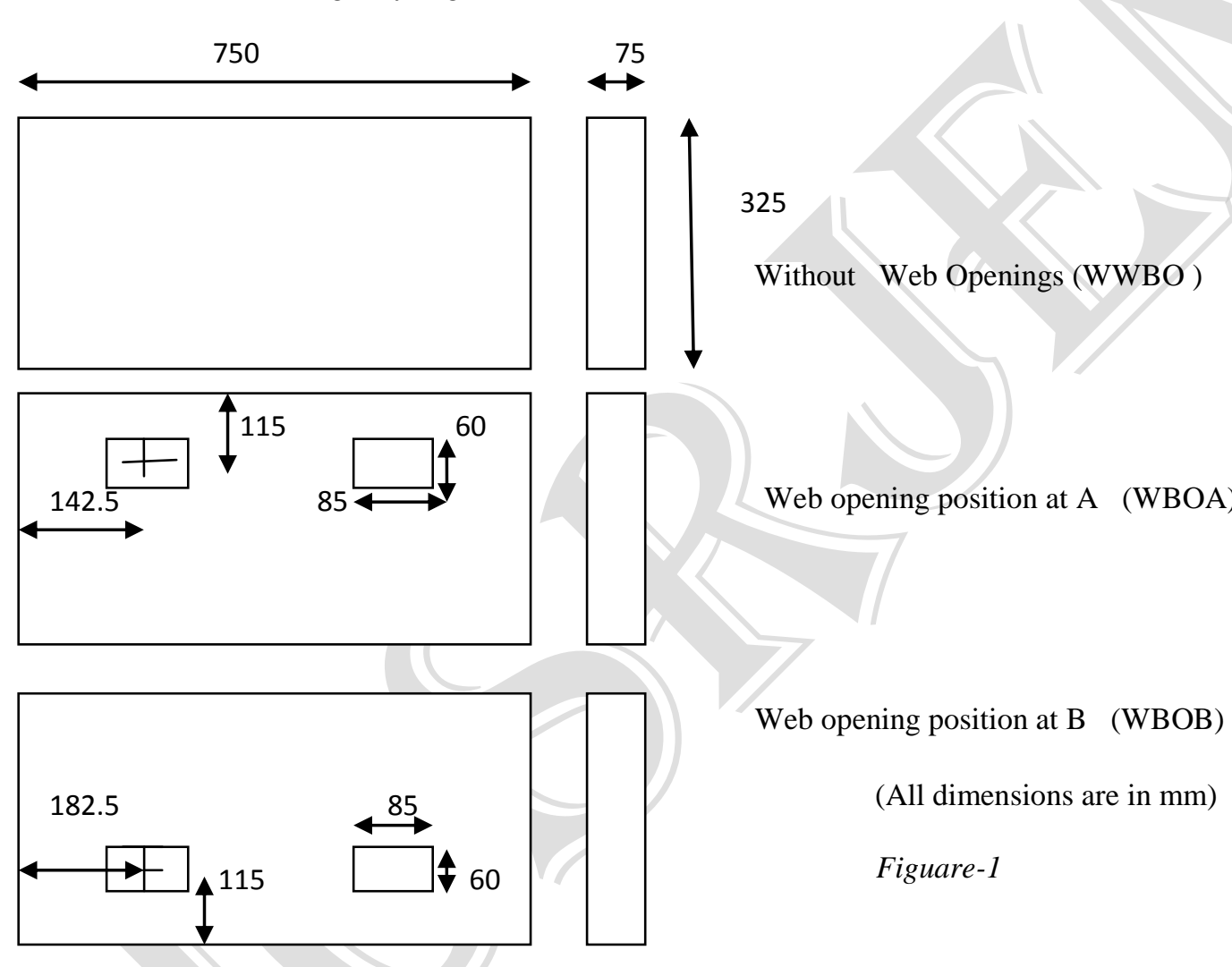

\section{Experimental Programme}

The deep beams were tested in a 60T capacity Universal Testing Machine. All the beams were tested to failure under two- point loading system. The test set up for the beam is shown in fig(2).

Each of the beam specimens were mounted on roller supports on the Universal Testing Machine. Three deflectometers were placed at the bottom fare of the beam at mid span and under the loading points. Two-point loads were obtained by placing the loading head on the top surface at the centre of the beam and distributing the load through a spreader beam. A small pre load was applied slowly to ensure that the beam was properly seated and the deflectometers were functioning properly. The load was then removed, reapplied and again removed slowly. Successive loads were applied in increments of $10 \mathrm{KN}$. Deflections at the mid-span and under the loading points were recorded at each load increment. During the test, the first -crack load was observed and the crack propagation carefully marked. All the beams were loaded to failure. Based on the tests results, standard specimens for the various 


\section{V.Vengatachalapathy, Dr.R.Ilangovan / IOSR Journal of Engineering (IOSRJEN) wWw.iosrjen.org \\ ISSN : 2250-3021}

Vol. 2 Issue 2, Feb.2012, pp.348-355

of addition of steel fibers. The optimum fiber content as $0.75 \%$ to $1.0 \%$. The main specimens (deep beams)were casted with $0 \%, 0.75 \%$ and $1.0 \%$ and were tested to failure.

Cubes of size $150 \mathrm{~mm}$ that had been cast along with the slabs were tested on the same day on which the respective slabs were tested to ascertain the compressive strength of the concrete used in the slabs. The cube tests were carried out in a Compression Testing machine of 200 ton capacity and these tests were carried out as per the recommendations of Indian Standard Codes of Practice.

The modulus of elasticity of steel fiber reinforced concrete deep beam was determined by conducting compression tests on SFR Cylinders that had been cast along with the deep beams. The test was conducted in a UTM and the deformations corresponding to the various loads were measured by a dial gauge. These tests were carried out as per IS-code recommendation.
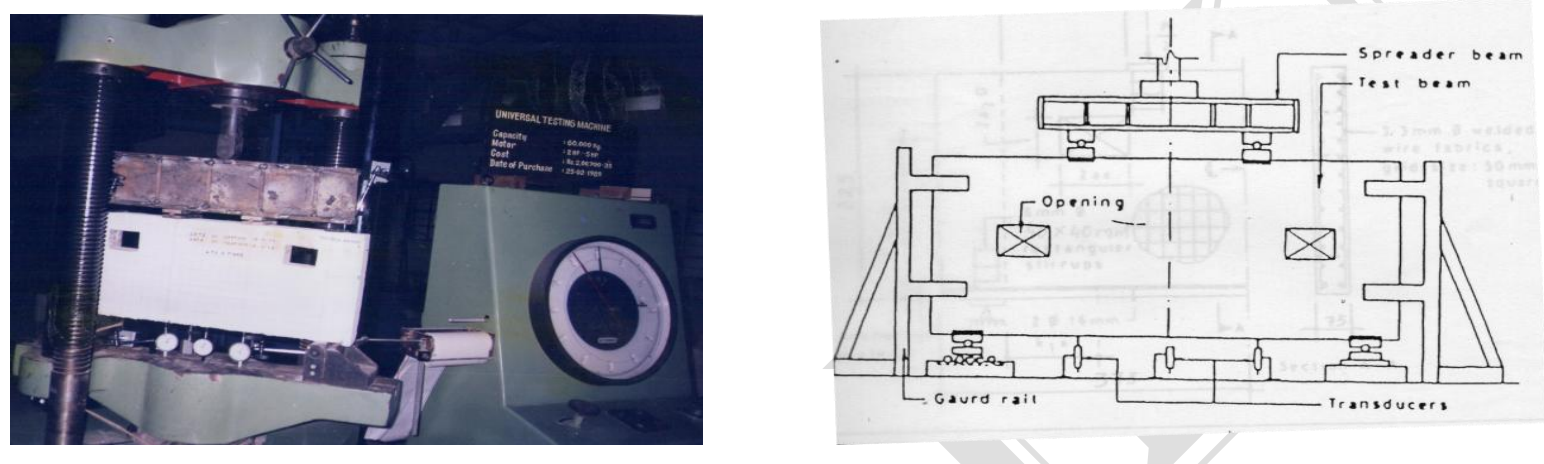

Figure 2, Test setup for deep beams

\section{BEHAVIOUR OF DEEP BEAMS DURING TESTING}

\section{Formation of cracks}

All seven beams were tested and all of them failed in shear. All beams were loaded to failure. The beams collapsed due to excessive destruction of concrete in the shear span. The crack patterns and failure of test specimens are shown in fig(3). The numbers written along the cracks indicate the termination of cracks observed at a particular stage. The first cracks were formed in the region of maximum bending moment between $50 \%$ to $60 \%$ of the ultimate load a sudden major inclined crack was formed almost in the middle of the shear span. The first crack was usually a suddenly inclined shear crack originating from the outer bottom corner of the opening. With further increase of load cracks propagated towards the support while crack originating at the top inner corner of the opening propagated upward towards the load bearing plate. Other flexural and flexural shear cracks were subsequently formed and propagated upwards.

At about 80 to $90 \%$ of ultimate load, new inclined cracks were formed parallel to the line joining the load edge and support blocks. Also at about the same load level tension vertical cracks appeared over the supports. This is the results of the thrust's eccentricity which essentially acts along the inclined crack. Finally, beam failure occurred by concrete destroyed in either the reduced compression zone at the head of the inclined crack and the region adjacent to the loading block or by fracture of the concrete along the inclined cracks. 


\section{V.Vengatachalapathy, Dr.R.Ilangovan / IOSR Journal of Engineering (IOSRJEN) www.iosrjen.org

Vol. 2 Issue 2, Feb.2012, pp.348-355
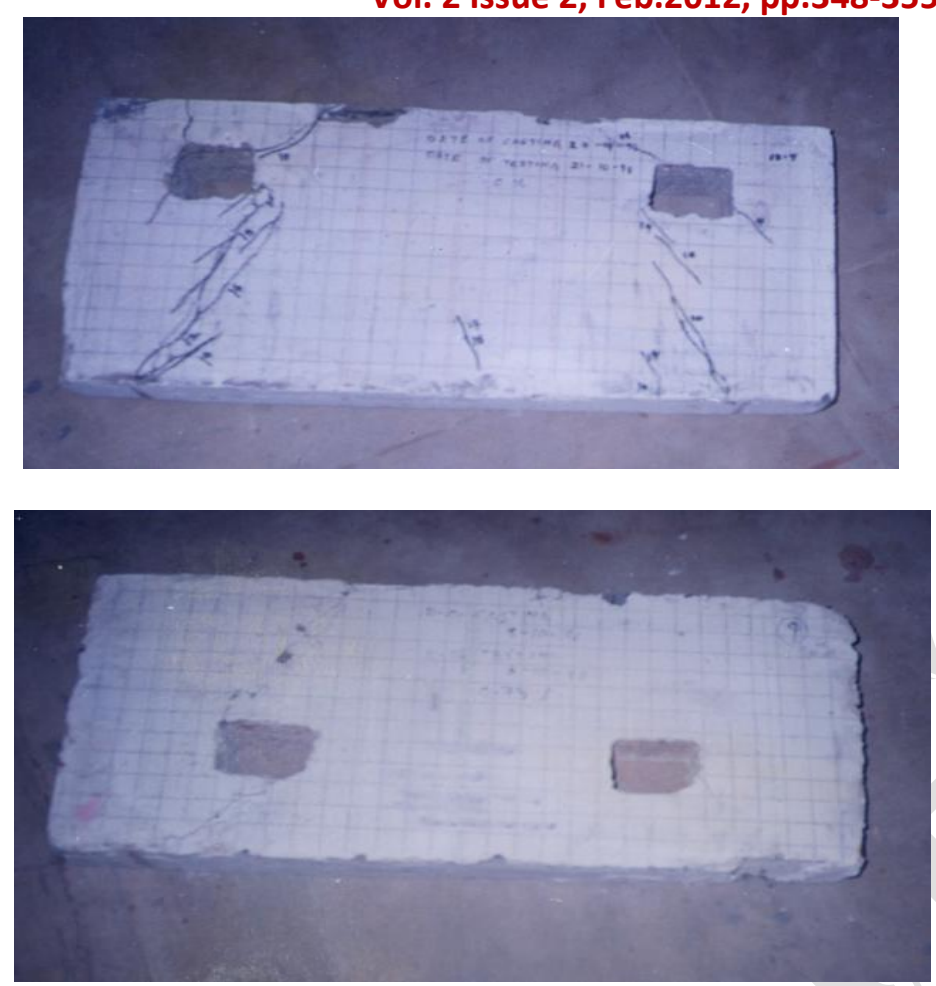

a) WBOA

Figure 3, Deep beams (after testing)

\section{Crack and cracking width}

The first major inclined crack appears in the shear span. This was a sudden crack that usually originated in the middle of the shear span and propagated towards the supports and loading joint from a subsequent increase in applied load. Test indicates that crack width tends to increase with load especially at loads higher than inclined cracking loads. Cracks were almost uniform on both sides of the beam. Maximum crack width along the major inclined crack in the shear span occurred almost at mid depth of the beam.

From graph1,Shear strength vs opening position and comparison of theoretical load and experimental load with respect to opening in web area of deep beam, the values are very close to estimated values. There was a reduction in the shear of the beams resulting in higher rate of deflection. It is also observed that the stiffness of the beam depend largely on the extent to which the openings interrupt on the load path. 


\section{V.Vengatachalapathy, Dr.R.Ilangovan / IOSR Journal of Engineering (IOSRJEN)}

www.iosrjen.org

Vol. 2 Issue 2, Feb.2012, pp.348-355



Graph 1, Shear capacity Vs Opening position of deep beams

\section{ANALYSIS OF THE TEST RESULTS}

The proposed Kong and Sharp's formula for reinforced concrete deep beams required modification to address the presence of steel fibres that provides extra shear capacity, fracture toughness and crack arrest.

Shanmugam and Swaddiwudhipang suggested the following modified form for ultimate shear capacity $(\mathrm{Pu})$ of fiber reinforced concrete deep beams containing openings.

$\mathrm{Pu} / 2=\mathrm{C} 1 \mathrm{f} 1 \mathrm{f} 2(1-0.36 \mathrm{x} / \mathrm{d}) \mathrm{ftn} \mathrm{b} \mathrm{D}+\sum \lambda \mathrm{C} 2 \mathrm{~A}(\mathrm{y} / \mathrm{D}) \sin 2 \alpha$

$\mathrm{C} 1 \quad=1.0$

$\mathrm{C} 2=300 \mathrm{~N} / \mathrm{mm} 2$ for deformed bars

f1 = (1- a1)(1-1.667 a2),the reduction factor for the size of the opening

$\mathrm{f} 2=\mathrm{h}+2(\mathrm{k} 2) \mathrm{rX}(((\mathrm{k} 1-\mathrm{k} 2) 2 /((\mathrm{a} 1 \mathrm{x}) 2+(\mathrm{a} 2 \mathrm{D}) 2)) 1 / 2 \leq 1.0$, the reduction factor for interruption of the opening on the radial load parts

$\mathrm{N}=1.1$ for steel fiber

$\lambda \quad=1.5$ for web bar and 1.0 for main bar

$\mathrm{h} \quad=0.6-2 \mathrm{k} \geq 0.2$

$\mathrm{r} \quad=1.0$ for centre opening is in the unloaded quadrant and 2.0 for loaded quadrant

$\mathrm{b}$ the width of the beam, $\mathrm{X}$ the clear span, $\mathrm{D}$ over all depth of the beam, $\mathrm{y}$ the depth at which a steel bar intersects a potential critical diagonal crack, $\alpha$ is the angle of intersection , $\mathrm{A}$ is the area of the steel provided, $\mathrm{ft}$ is the split tensile strength and a1, a2 ,k,\& k1 the coefficients defining the size and position of the openings. 


\section{V.Vengatachalapathy, Dr.R.Ilangovan / IOSR Journal of Engineering (IOSRJEN) www.iosrjen.org \\ ISSN : 2250-3021}

Vol. 2 Issue 2, Feb.2012, pp.348-355

The calculated theoretical shear capacity as given in the table(2) by using above formula.

The comparison of the experimental failure load with theoretical results in table(2) shows that the modified Kong and Sharp's formula, provides theoretical predication and it is matching with experimental values. The observation of the failure load listed in table(2) in conjunction with the beam geometry confirms that the effect of web opening on the load-carrying capacity of deep beams depends largely on the percentage of fiber interrupt the load pat. The greater degree of interruption, the greater is the reduction in shear strength.

The observation shows that the first crack load was found to shear strength increase $5 \%$ to $10 \%$ for the fiber reinforced beams and the beams did not crumble and fell down. The observations also show that for an optimum percentage of $0.75 \%$ by volume, gives maximum ultimate load for the deep beams.

Hence the results presented here in support the postulates that shear strength of deep beams depends greatly on the degree of interruption of the opening on the natural load path and also the percentage of fiber content present in the beam and openings in the tension zone weaken the beam. The modified Kong and Sharp's formula provides the accurate prediction of the ultimate shear strength of fiber reinforced concrete deep beams with and without web openings.

Table 1, Deflection at bottom of beam

\begin{tabular}{|c|c|c|c|c|c|c|c|c|c|c|}
\hline \multirow{2}{*}{ S.No } & \multirow{2}{*}{  } & \multicolumn{3}{|c|}{$\begin{array}{l}\text { Deflection at mid point- } \\
\text { (fiber-0\%) }\end{array}$} & \multicolumn{3}{|c|}{$\begin{array}{l}\text { Deflection at mid point- } \\
\quad \text { (fiber- } 0.75 \%)\end{array}$} & \multicolumn{3}{|c|}{$\begin{array}{l}\text { Deflection at mid point-(fiber- } \\
\qquad 1.0 \%)\end{array}$} \\
\hline & & $\begin{array}{l}0 \\
3 \\
3\end{array}$ &  & $\begin{array}{l}\text { \% } \\
\overbrace{}^{\infty}\end{array}$ & $\sum_{3}^{0}$ & 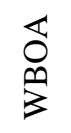 & $\begin{array}{l}\text { o } \\
\sum^{\infty}\end{array}$ & $\sum_{\substack{0 \\
3}}^{\infty}$ & 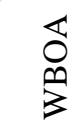 & \begin{tabular}{l}
$\infty$ \\
\multirow{0}{*}{} \\
3
\end{tabular} \\
\hline 1 & 00 & 0.0 & 0.0 & 0.0 & 0.0 & 0.0 & 0.0 & 0.0 & 0.0 & 0.0 \\
\hline 2 & 20 & 1.31 & 0.43 & 0.18 & 0.58 & 0.44 & 0.5 & 1.18 & 0.19 & 0.48 \\
\hline 3 & 40 & 1.96 & 0.61 & 0.79 & 0.96 & 0.98 & 0.69 & 1.26 & 0.26 & 0.52 \\
\hline 4 & 60 & 2.16 & 0.98 & 0.91 & 1.0 & 1.62 & 0.83 & 1.46 & 0.65 & 0.64 \\
\hline 5 & 80 & 2.22 & 1.62 & 1.18 & 1.28 & 1.96 & 1.12 & 1.76 & 1.2 & 0.72 \\
\hline 6 & 100 & 2.26 & 2.02 & 1.38 & 1.44 & 2.34 & 1.92 & 2.08 & 1.6 & 0.96 \\
\hline 7 & 120 & 2.31 & 2.36 & 1.98 & 1.78 & 2.82 & 2.32 & 2.38 & 1.72 & 1.28 \\
\hline 8 & 150 & 2.43 & 3.12 & 2.69 & 2.0 & 3.01 & 2.98 & 2.72 & 2.1 & 1.92 \\
\hline 9 & 160 & 2.44 & 3.42 & & 2.18 & 3.12 & 3.12 & 2.98 & 2.12 & 2.18 \\
\hline 10 & 180 & 2.53 & & & 2.45 & 3.18 & 3.31 & 3.12 & 2.3 & 2.83 \\
\hline 11 & 200 & 2.60 & & & 2.98 & 3.32 & & 3.26 & 2.61 & \\
\hline
\end{tabular}




\section{V.Vengatachalapathy, Dr.R.Ilangovan / IOSR Journal of Engineering (IOSRJEN)}

www.iosrjen.org

ISSN : 2250-3021

Vol. 2 Issue 2, Feb.2012, pp.348-355

Table 2, Experimental -Analytical results for deep beams

\begin{tabular}{|c|c|c|c|c|c|c|}
\hline \multirow{2}{*}{$\begin{array}{c}\text { Opening } \\
\text { Position }\end{array}$} & \multicolumn{2}{|c|}{ Fiber-0\% } & \multicolumn{2}{c|}{ Fiber -0.75\% } & \multicolumn{2}{c|}{ Fiber -1.0\% } \\
\cline { 2 - 7 }$(\mathrm{kN})$ & Exp value & $\begin{array}{c}\text { Theoretical value } \\
(\mathrm{kN})\end{array}$ & $\begin{array}{c}\text { Exp value } \\
(\mathrm{kN})\end{array}$ & $\begin{array}{c}\text { Theoretical } \\
\text { value } \\
(\mathrm{kN})\end{array}$ & $\begin{array}{c}\text { Exp value } \\
(\mathrm{kN})\end{array}$ & $\begin{array}{c}\text { Theoretical } \\
\text { value } \\
(\mathrm{kN})\end{array}$ \\
\hline $\begin{array}{c}\text { Without web } \\
\text { opening } \\
\text { (WWBO) }\end{array}$ & 208.50 & 211.69 & 243.00 & 233.32 & 224.50 & 230.16 \\
\hline $\begin{array}{c}\text { Web opening at } \\
\text { A(WBOA) }\end{array}$ & 176.40 & 176.35 & 238.90 & 191.04 & 213.50 & 188.90 \\
\hline $\begin{array}{c}\text { Web opening } \\
\text { position at } \\
\text { B(WBOB) }\end{array}$ & 168.50 & 168.48 & 194.20 & 181.62 & 184.50 & 179.70 \\
\hline
\end{tabular}

The physical properties of concrete, maximum compressive strength achieved at $0.75 \%$ fiber added to concrete and tested values are as shown in table(3). Fiber content of $0.75 \%$ by volume of the beam improves the shear strength.

Table 3, Physical properties of concrete

\begin{tabular}{|c|c|c|c|c|c|}
\hline Sl.No & $\begin{array}{c}\text { Fiber } \\
\text { content }\end{array}$ & $\begin{array}{c}\text { Avg. cube } \\
\text { compressive } \\
\text { strength(N/mm2) }\end{array}$ & $\begin{array}{c}\text { Avg. Split tensile } \\
\text { strength(N/mm2) }\end{array}$ & $\begin{array}{c}\text { Modulus of } \\
\text { elasticity }\end{array}$ & $\begin{array}{c}\text { Avg. density of } \\
\text { concrete(N/MM2) }\end{array}$ \\
\hline 1 & $0.0 \%$ & 27.1 & 2.57 & 29715 & 24.52 \\
\hline 2 & $0.25 \%$ & 28.86 & 2.60 & 30034 & 25.31 \\
\hline 3 & $0.5 \%$ & 29.12 & 2.7 & 30346 & 25.45 \\
\hline 4 & $0.75 \%$ & 30.14 & 3.0 & 31178 & 25.60 \\
\hline 5 & $1.0 \%$ & 30.42 & 2.96 & 31113 & 25.62 \\
\hline
\end{tabular}




\section{V.Vengatachalapathy, Dr.R.Ilangovan / IOSR Journal of Engineering (IOSRJEN) \\ www.iosrjen.org \\ ISSN : 2250-3021}

Vol. 2 Issue 2, Feb.2012, pp.348-355

\section{CONCULATION AND SUGGESTION FOR FURTHER WORK}

1. Web openings may be provided away from shear zone area of the beams and fiber content of $0.75 \%$ by volume may be added to improve the strength of the structure.

2. The opening in the shear zone weaken the beam.

3. Fiber content of $0.75 \%$ by volume of the beam improves the shear strength

4. Additional of steel fibers increase the tensile strength of concrete matrix and also increase in the Shear capacity of the beam.

\section{Suggestion for further work}

1. Different location of openings in the web may be tried with the same fibres for a bigger size specimens.

2.The experimental investigation may be carried out for fiber with different size.

3.Openings with different geometry in the web may be tried with the same fiber.

4. Studies may be carried out with different size of weld mesh as a web reinforcement.

5. In the openings area may be stiffened with additional reinforcement may be studied.

\section{Acknowledgement}

The kind cooperation from Dr.I.Ilangovan Assistant professor- Assistant professor Dept,of civil Engg. Mr.Balakrishnan, Mr.Balasubramanian and Mrs. Radhika,

\section{Reference}

[1] KONG,F.K.,ROBINS,P.J.,SINGH \& SHARP,G.R.,Deep beams with inclined web reinforcement, American concrete institute journal, Col.

[2] LEONHARADT,F.Discussion of :Strength and behavior of deep beams in shear by H.A.R.de Paiva and C.P.Siess.Proceedings of the American Sociatity of Civil Engineers.Vol.92,No.ST 2.April 1972.

[3] KONG,F.K.,ROBINS,P.J.,SINGH \& SHARP,G.R.,Shear analysis and design of reinforced concrete deep beams, the structural engineer,Vol.50,No.10,October 1972.

[4] PRABHAT,K.,Collapse load of deep reinforced concrete beams, Magazine of concrete Research,Vol.28,No.94,March 1976.

[5] SHANMUGAM,N.E and SWADDIWUDHIPONG,S., The ultimate load behavior of fiber reinforced concrete deep beams, the Indian concrete Journal Vol.58,No.8,November 1984 